\title{
WHO IS RESPONSIBLE FOR LOADING OPERATIONS, STOWAGE AND SECURING WITH RESPECT TO THE CARRIAGE OF CONSIGNMENTS?
}

\section{KRZYSZTOF WESOŁOWSKI}

University of Szczecin, Faculty of Management and Economics of Services, POLAND

e-mail: krzysztof.wesolowski@wzieu.pl

\begin{abstract}
RECEIVED
6 November 2018

ACCEPTED

3 December 2018

JEL

CLASSIFICATION

K12

KEYWORDS

contract of carriage of consignments, loading operations, securing the consignment

ABSTRACT The subject of this article is to identify persons responsible for carrying out loading operations, inclusive of the stowing of the consignment on the vehicle and operations in the form of securing the consignment for the time of carriage in international transport. The author, interpreting individual international conventions autonomously, based on the views of the science of law and the rich case law of the European courts, has tried to formulate the rules applicable in this respect in particular branches of transport.
\end{abstract}

\section{Introduction}

A translocation of a consignment, which is a characteristic performance resulting from a contract of carriage, must be preceded by a series of operations in the form of preparing the consignment for carriage (its packaging, marking), loading it, stowing it on the means of transport and appropriate security and prevention of movement of the consignment or its overturning during carriage. These activities play a major role from the perspective of the 
correctness of the performance of carriage. Apart from events which are the obvious cause of damage, such as traffic accidents, theft or arson, in the vast majority of cases concerning the carrier's liability, the dispute concerns the fact whether the above mentioned activities have been performed correctly and who was liable for them. Whereas in the case of securing the consignment for transport there is no doubt that the liability in this respect rests with the consignor, in the case of other activities, it is not so obvious. The regulations governing the contract of carriage of consignments often ignore this problem. This gives rise to disputes in legal science and case law.

The objective of this article is an attempt to answer the question contained in its title, in relation to carriage performed within the framework of international conventions applicable to carriage by rail, ${ }^{1}$ by road ${ }^{2}$ and by air. ${ }^{3}$ Remarks in this respect will be preceded by the determination of the qualification of the contractual provisions relating to pre-carriage activities.

\section{Qualification of the contractual provisions relating to pre-carpiage activities}

Preparation of the consignment for carriage, loading of the consignment, similar to its stowage on the means of transport and its securing, do not constitute the essence of the characteristic performance resulting from the contract of carriage. International conventions governing the contract of carriage do not, therefore, treat the abovementioned activities as an essential element of the contract of carriage. This raises the question of how to deal with contractual terms which impose obligations in this respect on one of the parties to the contract of carriage. Are they additional provisions of the contract of carriage or do they form a separate contract in this respect, independent from the contract of carriage (especially if, for example, the carrier charges a separate fee for such activities; in Polish law such a contract would be treated as a contract for a specific task). In practice, the problem concerns loading operations and the stowage of the consignment on the means of transport performed by the carrier.

Pragmatic grounds strongly support the first of the possible positions. If the parties to the contract of carriage agree by whom the activities in question are to be performed, these agreements should be treated as accidentalia negotii of the contract of carriage itself. Therefore, the view that in the situation discussed, a separate contract for the performance of loading operations, separate from the contract of carriage, is concluded should be rejected [such a view is presented in a paper (Hill, Messent, Glass, 2000, p. 104). However, a different view is presented in (Clarke, 2009, p. 270)]. The classification criticized here would be manifestly artificial. The loading or stowage of a consignment on a means of transport are linked inherently to the translocation itself. Classification of the provisions which concern them as a separate agreement would lead to the division of the carrier's responsibility for the loading or stowage of a consignment and for the translocation itself. Damage of the same type (e.g. damage to a consignment) would be assessed differently depending on the moment at which it was caused (as a rule, liability for non-performance or improper performance of loading operations would have to be assessed more mildly, on the basis of general provisions on contractual liability, than liability for damage caused during the carriage itself, under

\footnotetext{
${ }^{1}$ Convention concerning International Carriage by Rail (COTIF) of 9 May (Dz.U. 1985, no. 34, item 158), as amended by the Vilnius Protocol of 3 June 1999 (Dz.U. 2007, no. 100, item 674), Appendix B. Uniform Rules concerning the Contract of International Carriage of Goods by Rail (CIM).

${ }^{2}$ Convention on the Contract for the International Carriage of Goods by Road (CMR) and protocol of signature of 19 May 1956 (Dz.U. 1962, no. 49, item 238 as amended).

${ }^{3}$ Convention for the Unification of Certain Rules for International Carriage by Air of 28 May 1999 (Dz.U. 2007, no. 37, item 235) - Montreal Convention.
} 
the framework of transport regulations). It would often lead to doubts as to the application of the relevant provisions. It should therefore be assumed that, where loading operations are entrusted to the carrier in a contract, they are covered by the carrier's liability regime under the applicable Convention. The entrustment of the goods to the carrier takes place at the moment when they became available to him for loading. Likewise, the goods are released to the consignee through placing them at the disposal of the consignee and through their acceptance (albeit implicit), after unloading.

\section{Loading operations (loading and stowing the consignment on a means of transport)}

The CIM Convention, as only one of the international conventions governing the contract of carriage mentioned, regulates the problem in question. Article 13 (1) of this Convention imposes an obligation on the parties to the contract of carriage to determine the entity liable for performing the loading operations. At the same time, it introduces a rule, applicable in the absence of such arrangements, under which loading operations with respect to small consignments are the responsibility of the carrier and the operations with respect to the wagon consignments are the responsibility of the consignor and the consignee, respectively. As seen from the above, the only criterion of selection of the entity obliged to perform loading activities is the type of consignment. The provision does not contemplate any other circumstances, such as, for example, the place of loading (consignor's siding, railway station). In its previous version, Article 20 of the $1980 \mathrm{CIM}$ regulated this problem by referring to the regulations in force at the loading station. In this version too, however, it was relatively binding (cf. Clarke, Yates, 2008, p. 149).

On the other hand, the CMR Convention does not regulate directly who is obliged to perform loading operations. In this respect, it does not even contain a dispositive norm. The issue should be assessed first of all in the context of the agreement between the parties. It happens that the problem in question is not so much regulated by the agreement itself, but by terms and conditions to which the agreement refers (see an interesting decision of the Belgian Tribunal de Commerce de Malines of 18.11.1999, ETL 2000, 432-441, in which the court confirmed the carrier's liability for damage resulting from defective loading and securing, based on his signature on the consignment note, referring to the terms and conditions of carriage under which liability for loading and protection was attributed to the carrier, even if these operations were actually performed by the consignor. The Court noted that the carrier was a specialist in loading and securing the load and that he had made no reservations as to the consignment note).

The situation becomes more complicated in the absence of contractual provisions. In such a situation, it is sometimes assumed that the governing law is national law. In Poland, it would be governed by a relatively binding provision of Article 43 of the Act of 15 November 1984 - Transport Law (Dz.U. 2017, item 1983), which imposes this duty on the consignor or a consignee [an example of the application of national law to the determination of the entity responsible for loading and stowing the consignment on the vehicle is the German BGH judgment of 25 January 2007, ETL 2007, 766-773; the application of the national law norms to the appointment of a person obliged to perform loading operations is supported, inter alia, by (Rodière, 1970, pp. 630-633; Clarke, 2009, p. 73; Basedow, 1997, Articles 8, p. 13; see to the contrary Loewe, 1976, p. 366 and Putzeys, 1981, par. 792)].

However, far-reaching restraint when it comes to the application of national law in this area is necessary. This is supported, for example, by the fact that the activities in question are often carried out in completely different countries from the country whose law is applicable to deciding matters not regulated by the Convention. It therefore seems more appropriate to seek a solution to the problem in question under the framework of the convention itself, 
applicable to the transport in question, by interpreting its provisions. The customs and accepted practice between the parties, as well as other circumstances of a given case are also relevant. An example of such an approach is the judgment of Cour d'Appel d'Anvers of 19 February 2001, ETL 2001, 242, in which the court stated that if there are no contractual provisions specifying who is responsible for the operations in the form of stowage of the consignment, it is necessary to determine on the basis of the circumstances of a given case who is responsible for performing these actions. The court did not exclude the situation in which, on the basis of the facts established, the liability for damage resulting from improper stowage of the consignment may be divided between the carrier and the shipper (acting on behalf of the consignor). The same court, in its judgment of 27 May 2002, JPA 2002, 131-150, also ordered that in the absence of contractual arrangements, the circumstances of the case, such as the type of goods, the parties' knowledge of the characteristics of the goods and the rationality of the choice should be taken into account. In principle, a better knowledge of the characteristics of the goods forwarded by the consignor was pointed out, inter alia, in the judgements of Cour d'Appel de Gand of 19 January 1999, ETL 1999, 264-274, judgement of the Tribunal de Commerce d'Anvers of 1 February 1996, ETL 1996, 579-584.

On the other hand, the OGH, in its judgment of 13 January 2003, ETL 2004, 244, explained that if defects of a vehicle were found (lack of lashing) and at the same time the manner of loading and stowage of the consignment, which were performed jointly by the so-called shipper acting on behalf of the consignor and the carrier, were questionable, the essential issue is who had a duty to perform these actions. In doubtful cases it should be assumed that the loading of the consignment is the responsibility of the consignor, hence the mistake made by the shipper is not a circumstance for which the carrier is responsible.

For the proper solution of the issue in question, the nature of carriage is also relevant. In the case of carriage by road, as door-to-door carriage, as a rule, the acceptance of goods for carriage as well as their release to the consignee takes place at the customer's premises and not at the carrier's check-in desk (as it is the case, for example, with carriage by air or some railway consignments). It is actually the customer who has personal and technical means (stackers, cranes, ramps, etc.) enabling these activities to be carried out [this is pointed out by (Rodière, 1970, p. 632); similar views are expressed in the Belgian case law cited by (Theunis, 1987, p. 88), see also: judgement of Belgian Courd'Appeld'Anvers of 27 September 1999, JPA 2000, 43-54]. In this situation, it should therefore be assumed that under the framework of CMR, unless the parties agree otherwise and, subject to other circumstances, the loading activities are the liability of the consignor or the consignee.

This is confirmed, albeit indirectly, by the regulation contained in Article 17 (4)(c) of the CMR, according to which the carrier is not liable if the loss of or damage to the goods is due to a particular hazard arising from handling, loading, stowage or unloading of the goods by the consignor or the consignee, or by persons acting on behalf of the consignor or the consignee. Although it cannot be inferred from that provision that in any event the loading operations are the responsibility of the consignor or the consignee, in the absence of any provision imposing obligations on the carrier in this respect, the conclusion that these operations are, in principle, the responsibility of those persons seems obvious [such is also the position of the Austrian courts, for example in the judgement of the OGH of 21 March 1977, TR 1982, 111; judgement of the OGH of 8 October 1984, Strassengüterverkehr 1985, 6, 28 and a judgement of the OGH of 3 July 1985, Strassengüterverkehr 1986, 2, 10; see also: (Greiter, 1986, 239, 242, 270 and 274); the opposite view prevails however, in the case law of the French courts, which tend to accept the carrier's responsibility for loading, unless it is necessary to use special equipment in the possession of the consignor; cf. (Rodière, 1970, pp. 630-631)]. 
It is characteristic that the aforementioned provision of Article 17 (4)(c) of the CMR provides not only for loading operations in the strict sense of the term (i.e. placing goods on a means of transport), but also for handling ${ }^{4}$ and stowage (meaning the placing at a specific location on the means of transport) of the goods on a means of transport. It should be assumed that these activities also, in principle, are the responsibility of the consignor or the consignee, especially since they are closely linked to loading or unloading.

Furthermore, the Montreal Convention does not regulate the issue of the person obliged to carry out the loading operations. However, the situation in this mode of transport seems to be different from that of the road transport. In the case of air transport, it is difficult to imagine that the loading of the consignments carried could be placed exclusively in the hands of the consignor. This is primarily determined by security considerations. Therefore, the operations in question are entrusted exclusively to entities authorized to operate on the premises of a given airport. Issues of authority are regulated by provisions of an administrative nature. ${ }^{5}$ However, this conclusion does not solve the problem as to which of the parties to the contract of carriage should delegate such operations to a specialized entity operating at the airport and, consequently, who is responsible for the improper performance of such operations in relationships arising from the contract of carriage. Since it is difficult to obtain any guidance in this respect from the provisions of the Convention (also from the provisions on exempting from liability, as in the case of the CMR), it should be assumed that this has been left to the parties to decide. On the other hand, the procedures for concluding contracts for the carriage of goods by air, and in particular the recourse to the services of specialized forwarding companies while sending consignments for carriage, generally eliminates the risk of leaving the matter unarranged.

The determination of the party responsible for performing the loading operations makes this party responsible for their proper performance, even if de facto, these operations were performed by the other party to the contract. We may also refer to the judgement of the OLG of Munich of 28 January 2004, TR 2004, 324-236, in which a position was taken that a driver who has not received loading instructions from the carrier, carrying out the operations in question, acts as the consignor's agent following his instructions.

It happens, however, that a party which is not obliged to carry out loading operations, performs them on its own initiative without the consent of the party obliged. This may result from the haste of the carrier, which is particularly characteristic of road transport. In such a case, it cannot be disputed that responsibility for improperly performed operations must rest with the party performing them (see the judgment of the Cour d'Appel de Liege of 18 December 1967, ETL 1969, 965-974, in which it was stated that it was the carrier who was solely responsible for improper loading and stowage if he did it on his own initiative without appropriate arrangements with the consignor).

${ }^{4}$ The concept of handling derives from transport by sea, where it means moving loads within a port, repacking, combining, marking, sorting, drying, cleaning and taking samples. See Młynarczyk (2005), p. 455.

${ }^{5}$ In Poland these issues are regulated by a Regulation of the Minister of Transport, Construction and Maritime Economy of 19 November 2013 on ground handling at airports issued based on Article 182 of the Act of 3 July 2002 Aviation Law (Dz.U. 2018, item 1183). 


\section{Securing the consignment for the duration of carpiage}

The attribution to one of the contracting parties of the obligation to load and stow the consignment does not automatically mean that this party is responsible for carrying out operations to secure the consignment on the means of transport. In particular, the abovementioned arguments in support of the carrier's lack of technical capacity to perform loading operations do not apply to securing the consignment. Although their performance is not explicitly mentioned as one of the carrier's obligations under international conventions, the obligation in this respect can be deduced from the general principle related to the duty of care over the consignment and from the need to interpret strictly the conditions exempting the carrier from liability (the provisions defining these conditions - as providing for an exception to the carrier's liability for damage to the substance of the consignment occurred during carriage must be interpreted in a strict and not broad manner). The provision of Article 17 (4)(c) of the CMR, while listing operations for the effects of which the carrier is not responsible, does not mention securing the consignment for the duration of carriage. Similarly, Article $23(3)(c)$ of the CIM, which provides for a similarly formulated reason exempting the carrier from liability, only mentions loading operations.

It is also important here that securing the consignment for the duration of carriage directly affects safety of land and air traffic. This applies in particular to air and road transport (possibility of the consignment movement) and the obligations imposed on the carrier in this respect by virtue of binding rules of general application which must be correlated with the obligations imposed on the carrier in connection with the contract of carriage concluded. The latter circumstance could argue for also charging the carrier with the activities of stowing the consignment on the means of transport, however, in this case the argument concerning the actual possibility for the carrier to carry out those activities cannot be ignored. With regard to securing the consignment, it is impossible to assume, as a rule, that the carrier is not able to perform such operations if the consignment has already been stowed on the means of transport, even if its receipt for carriage takes place at the customer's premises and not at the checkin counter operated by the carrier. It must therefore be assumed that the carrier is, in principle, responsible for ensuring that the consignment is adequately secured for the duration of carriage (by means of lashing straps, mats, bars, ropes and the like) (see the longer argument on this point in the grounds of the judgment of the Cour d'Appel d'Anvers of 10 May 1999, JPA 2000, 212-229; this court noted that, even if the securing of the goods on the motor vehicle was carried out by the employees of the consignor, where the obligation to carry out these operations was imposed on the carrier, the actions of the personnel of the consignor must be regarded as actions of persons for which the carrier is liable within the meaning of Article 3 of the CMR. See also: the judgment of the Cour d'Appel de Bruxelles of 28 June 1969, ETL 1969, 925-930, in which the court accepted that, although the loading was the consignor's responsibility, the carrier should have secured the consignment because, as a professional, he had to ensure the stability of the vehicle and take appropriate measures with regard to road safety. Such was the judgement of the French Cour de Cassation of 11 June 2002, BTL 2002, 441-442).

However, by way of exception, the consignor is obliged to perform security actions when the consignment is accepted for carriage in a means of transport locked and sealed by the consignor or when the parties expressly agree that the consignor is responsible for securing the consignment for carriage. Such situations occur mainly in railway transport, in the case of wagon shipments shipped on railway sidings, although they also occur in road transport. In such a situation, however, the carrier is obliged to cooperate in the performance of these obligations, not least for the sake of ensuring traffic safety. 


\section{Conclusions}

In the light of the foregoing, the question of the party liable (and responsible) for the proper loading of the consignment on the means of transport, its stowage and securing, may be the subject of contractual agreements between the parties to the contract of carriage in all modes of transport. In their absence, only the CIM Convention explicitly regulates the problem with regard to loading operations. The other two conventions (CMR and the Montreal Convention) are silent on this issue. However, this does not lead to the same conclusions under both conventions, which is due to both differently defined reasons of exempting the carrier from liability (allowing for indirect conclusions to be drawn as to the existence or non-existence of obligations in this respect on the part of the carrier), and to the technical and technological differences of these modes of transport, which must be taken into account in the circumstances of the case as a whole. However, a conclusion may be justified that on the grounds of the CMR, the obligation to load the consignment and stow it on the means of transport rests, as a rule, with the consignor. On the other hand, it is generally the carrier's responsibility to secure the consignment from shifting (tipping over) during carriage. In air transport it is difficult to reach such an unambiguous conclusion. However, the operating conditions of airports require the use of professional operators involved in these activities, and the procedure for concluding a contract of carriage generally provides clarity in this respect. As a rule, security measures in rail transport (also not directly regulated) are the responsibility of the loading entity.

\section{References}

Basedow, J. (1997). Übereinkommen internationaler Straßenverkehr. In: Münchener Kommentar zum Handelsgesetzbuch. Band 7. München: Beck.

Clarke, M. (2009). International Carriage of Goods by Road: CMR. Maritime and Transport Law Library. London: Informa.

Clarke, M., Yates, D. (2008). Contracts of Carriage by Land and Air. Shipping Monograph Series. London: Informa.

Greiter, I. (1986). CMR - Gerichtsurteile. Eisenstadt: Prugg-Verlang.

Hill, D.J., Messent, A.D., Glass, D.A. (2000). CMR: Contracts for the International Carriage of Goods by Road. Lloyd's Shipping Law Library. London: Lloyd's of London Press.

Loewe, R. (1976). Commentary on the Convention of 19 May 1956 on the Contract for the International Carriage of Goods by Road (CMR). European Transport Law, 3, 347-487.

Młynarczyk, J. (2005). Nowe ujęcie międzynarodowej regulacji umowy przewozu ładunku morzem. In: Rozprawy prawnicze. Księga pamiątkowa Profesora Maksymiliana Pazdana (pp. 449-459). Kraków: Zakamycze.

Putzeys, J. (1981). Le Contrat de Transport Router de Marchandises. Brussels: Bruylant.

Rodière, R. (1970). The Convention on Road Transport. European Transport Law, 5, 620-637.

Theunis, J. (1987). International Carriage of Goods by Road (CMR). London-New York: Lloyd's of London Press.

1967.12.18 - Belgian Cour d'Appel de Liege, European Transport Law 1969, 965-974.

1969.06.28 - Belgian Cour d'Appel de Bruxelles, European Transport Law 1969, 925-930.

1977.03.21 - Austrian Obersten Gerichtshof, Transportrecht 1982, 111.

1984.10.08 - Austrian Obersten Gerichtshof, Strassengüterverkehr 1985, 6, 28.

1985.07.03 - Austrian Obersten Gerichtshof, Strassengüterverkehr 1986, 2, 10.

1996.02.01 - Belgian Tribunal de Commerced'Anvers, European Transport Law 1996, 579-584.

1999.01.19 - Belgian Cour d'Appel de Gand, European Transport Law 1999, 264-274.

1999.05.10 - Belgian Cour d'Appel d'Anvers, Jurisprudence du Port d'Anvers 2000, 212-229.

1999.09.27 - Belgian Cour d'Appeld'Anvers, Jurisprudence du Port d'Anvers 2000, 43-54.

1999.11.18 - Belgian Tribunal de Commerce de Malines, European Transport Law 2000, 432-441. 
2001.02.19 - Belgian Cour d'Appel d'Anvers, European Transport Law 2001, 242.

2002.05.27 - Belgian Cour d'Appel d'Anvers, Jurisprudence du Port d'Anvers 2002, 131-150.

2002.06.11 - French Cour de Cassation, Bulletin des Transports et de la Logistique 2002, 441-442.

2003.01.13 - Austrian Obersten Gerichtshof, European Transport Law 2004, 244.

2004.01.28 - German Oberlandesgericht München, Transportrecht 2004, 324-236.

2007.01.25 - German Bundesgerichtshof, European Transport Law 2007, 766-773.

Cite this anticle aS: Wesołowski, K. (2018). Who is responsible for loading operations, stowage and securing with respect to the carriage of consignments? European Journal of Service Management, 4 (28/1), 343-350. DOI: 10.18276/ejsm.2018.28/1-43. 